\title{
DEMOGRAFSKI RAZVOJ KRIVOPUTSKE MIKROREGIJE DINAMIČKE I STRUKTURNE PROMJENE U UVJETIMA ISELJAVANJA STANOVNIŠTVA
}

\author{
Dragica HUSANOVIĆ-PEJNOVIĆ \\ Učiteljski fakultet u Rijeci \\ Odsjek za učiteljski studij u Gospiću \\ Ante Starčevića 12, 53000 Gospić \\ Dane PEJNOVIĆ \\ Prirodoslovno-matematički fakultet \\ Geografski odsjek \\ Marulićev trg 19, 10000 Zagreb
}

\section{UVOD}

$\mathrm{P}$ rostorni pojam Krivoputska mikroregija odnosi se na šest prostorno izdvojenih naselja, razmještenih na raščlanjenoj zaravni jugozapadne padine Velike Kapele, u sjevernom dijelu Grada Senja. To su Alan, Krivi Put, Mrzli Dol, Podbilo, Veljun Primorski i Vrataruša (Ljubović 2008:54). Ukupno zapremaju površinu od $90,56 \mathrm{~km}^{2}$ na kojoj je 2001. godine zabilježeno 495 stanovnika.

Obzirom da u stručnoj literaturi ne postoji pojam Krivoputska regija, niti je uvriježen među lokalnim stanovništvom, to nalaže potrebu kratkog obrazloženja opravdanosti izdvajanja homogene prostorne cjeline, odnosno regije, pod navedenim naslovom. Prostorna individualnost promatranog dijela velikokapelske primorske padine u okviru Grada Senja temelji se na dva kriterija: prvo, izrazitim obilježjima tradicionalne (historijsko-geografske) regije i drugo, tradicionalnoj gravitacijskoj okupljenosti oko Krivoga Puta kao funkcionalnog središta.

Kada je riječ o tradicionalnim regijama, potrebno je napomenuti da je to specifičan oblik složenih prostornih cjelina, očuvanih u naslijeđenom prostornom okviru i svijesti stanovništva, koje su često u izvjesnom pomaku u odnosu na aktualni regionalni sustav. Pristup njihovom istraživanju temelji se na tri skupine kriterija: 1. kriteriju prirodne osnove, 2. teritorijalno-organizacijskom kriteriju i 3. socio-kulturnom kriteriju (Fürst-Bjeliš 1996:326). Krivoputska mikroregija homogena je s obzirom na sva tri izložena kriterija. Prvo, svojom prostornom izdvojenošću (sjeverno od duboko usječene poprečne udoline Senjske Drage), morfološkim obilježjima (glavninu prostora zaprema rasčlanjena visoravan između 500 i $850 \mathrm{~m}$ nv), kao i činjenicom što je to jedini dio potkapelske primorske padine unutar prostornog okvira Grada Senja, jasno se razlikuje od ostalih područja te jedinice lokalne samouprave. Drugo, značajan čimbenik oblikovanja prostornog okvira tradicionalne regije bila je i teritorijalna organizacija, kako komunalna, tako i crkvena. Povezano s tim, Krivi je Put već 1789. godine postao župsko središte, a 1807. osamostalio se u posebnu župu, proširenu priključivanjem Veljuna i Francikovca koji su do tada bili u sastavu župe Senjska Draga (Bogović 2008:70). Ipak, ključno značenje za javnu percepciju prostornog obuhvata krivoputske regije, imalo je formiranje Upravne općine Krivi Put u sastavu Upravnog kotara Senj u Ličkokrbavskoj županiji 1886. godine (Ljubović 2008:60). Na taj način stečen upravno-teritorijalni identitet dodatno je osnažen osnivanjem Šumske uprave Krivi Put u okviru Ogulinske imovne općine 1903. godine (ibid.). Naposljetku, obilježja krivoputskog prostora kao tradicionalne regije upotpunjuje i njegova pripadnost zapadnodinarskom socio-kulturnom arealu. To se neposredno očituje u kulturnom pejzažu, obilježenom disperznom strukturom naseljenosti, ${ }^{1}$ prevlašću dinarske graditeljske tradicije u profanoj ar-

Prevlast disperzne naseljenosti u Krivoputskoj mikroregiji potkrjepljuje podatak da se njegovih šest naselja sastoji od ukupno 62 statistička dijela naselja (zaseoka), što znači da svako naselje prosječno uključuje više od 10 dijelova naselja. Takva struktura naseljenosti posljedica je uvjeta i načina naseljavanja tog prostora početkom i 
hitekturi i okupljenim parcelama pojedinih gospodarstava (okupljenom posjedu), ali i karakterističnom novoštokavskom ikavskom govoru (usp. Čilaš Šimpraga 2008:124) te prepoznatljivom socio-psihološkim identitetom, temeljenom na dugotrajnom životu u porodičnim zadrugama i stočarskoj tradiciji.

$\mathrm{Uz}$ karakteristike tradicionalne prostorne cjeline, regionalna izdvojenost krivoputskog prostora $\mathrm{u}$ okviru Grada Senja, odnosno Senjske subregije, temelji se na tradicionalnoj funkcionalnoj okupljenosti oko Krivoga Puta kao lokalnog inicijativnog središta. Takva njegova uloga predodređena je središnjim položajem unutar mreže naselja tog dijela podkapelske primorske padine, posebno križišnim prometnim položajem, na sjecištu uzdužne županijske i poprečnih lokalnih cesta. Zahvaljujući takvom položaju, u tom su se naselju koncentrirale osnovne središnje funkcije - trgovina, gostionica, promet (pošta, autobusna postaja), škola, uprava (danas Mjesni odbor), župna crkva, a u novije vrijeme i sportski klub (NK Bunjevac) te udruga Vrisak, kojima je se u prošlosti zadovoljavalo, i danas zadovoljava, temeljne uslužne potrebe stanovništva tog dijela podkapelske primorske padine. Unatoč nadređenom značenju, izuzev par javnih zgrada, Krivi Put se fizionomski znatnije ne razlikuje od ostalih naselja Mikroregije; nema obilježja okupljenoga, već izrazito disperznog naselja (sastoji se od 10 statističkih dijelova naselja, odnosno zaseoka). Iako mu je zbog snažne depopulacije posljednjih desetljeća s jedne, i jačanja povezanog života s druge strane, većina središnjih funcija atrofirala, on je do danas zadržao svoju tradicionalnu ulogu lokalnog središta okupljanja sjevernog dijela područja Grada Senja. To dodatno opravdava izdvajanje Krivoputske mikroregije, kao funkcionalno homogene prostorne cjeline, gravitacijski okupljene oko Krivoga Puta.

Kao krški prostor i ruralna periferija, Krivoputska mikroregija klasični je emigracijski prostor. U znatnijem broju iseljavanje je započelo nakon razvojačenja Vojne krajine, od početka 70-ih godina 19. stoljeća i s promjenljivim se intenzitetom nastavilo do najnovijeg doba. $U$ ranijem razdoblju, od početka 1870-ih godina do Drugoga svjetskog rata, temeljni potisni čimbenik emigracije bila je agrarna prenaseljenost, kao rezultat nesklada između prekobrojnog stanovništva i ograničenih potencijala krške prirodne osnove u uvjetima tradicionalnog gospodarstva. Nakon Drugoga svjetskog rata, a pogotovo od početka 1960-ih godina, iseljavanje se odvijalo u uvjetima polariziranog razvoja Hrvatske, pod privlačnim utjecajima razvijenijih gradskih središta, te zapošljavanja u inozemstvu. Uzroci, pulsiranje i odredišta iseljavanja ovdašnjeg stanovništva podrobnije su izloženi u prvome svesku Monografije Živjeti na Krivom Putu (Šarić 2008:15-43; Ljubović 2008:49-67, Rajković 2008:79-94, Rajković, Jurković 2008:95-119). Dugotrajni, a povremeno i veoma intenzivan mehanički odljev stanovništva ostavio je duboke negativne posljedice na suvremeni demografski razvoj i strukturu naseljenosti promatranog prostira. To se neposredno očituje u uznapredovalom procesu starenja i demografskom izumiranju, što je sugestivno prikazano u radu M. Bogovića (2008:69-75).

Cilj je ovog rada kvantitativna analiza demografskog razvoja Krivoputske mikroregije s težištem na međupopisnom razdoblju 1991.-2001. U okviru toga pobliže će biti razmotrena dinamička i strukturna obilježja stanovništva u naseljima promatranog prostora, kao osnova za ocjenu stanja i procjenu perspektive razvoja naseljenosti u tom dijelu ruralne periferije Grada Senja.

\section{OPĆE KRETANJE STANOVNIŠTVA}

$\mathrm{O}$ d naseljavanja početkom i tijekom prve polovice 17. stoljeća broj stanovnika Krivoputske mikroregije postupno se povećavao pod utjecajem visokoga prirodnog prirasta. Prvim popisom stanov-

u prvoj polovici 17. stoljeća (Pavičić 1990:146). Bunjevački doseljanici bili su organizirani u porodične ili kućne zadruge. One su istovremeno bile krvne i socijalno-ekonomske zajednice, ali i posjedovne jedinice i naseobinske ćelije. Gospodarsku osnovu zadružnih domaćinstava činilo je ekstenzivno stočarstvo, uz koje se u manjoj mjeri prakticiralo i poljodjelstvo. Kako im je zbog takvog načina gospodarenja trebalo mnogo pašnjačkih i šumskih površina, zadružni je posjed uključivao razmjerno velik prostor, najvećim dijelom pašnjak unutar kojeg su bile razbacane obradive površine. Domaćinstva su se nastojala smjestiti, ukoliko je to bilo moguće, u sredini posjeda. Tako je nastao specifičan tip disperznih (raštrkanih gospodarstava s okupljenim posjedom koja su tijekom vremena prerasla u patronimičke zaseoke (nazvane prema prezimenu zadružnoga starješine, kućedomaćina), povezane u širu zajednicu sela (Pejnović 2007:37). Takvi, patronimički, zaseoci čine više od polovice ukupnog broja statističkih dijelova naselja Krivoputske mikroregije (usp. Korenčić 1979:603-609, Ljubović, 2008:52-54). 
ništva, kojega je provela vojnokrajiška uprava 1835. godine, u naseljima Krivi Put i Mrzli Dol (u sastavu Krmpotske kumpanije Ogulinske pukovnije) registrirano je 114 kuća s ukupno 1.574 stanovnika (Fras 1988:192), što znači da je svako zadružno kućanstvo prosječno brojilo skoro $14(13,8)$ članova. Dvadesetak godina kasnije, prvim modernim popisom stanovništva iz 1857. godine (kojim su obuhvaćena sva naselja na području tadašnje Habsburške Monarhije), u šest naselja današnje Krivoputske mikroregije ukupno je zabilježeno 2.545 stanovnika. Porast broja stanovnika nastavio se do početka 1880-ih godina, nakon čega je došlo do osjetnog demografskog regresa u razdoblju 1880.-1900. ${ }^{2}$ U prvom desetljeću 20. stoljeća ponovo je zabilježen porast broja stanovnika, tako da je 1910. godine zabilježen apsolutni maksimum naseljenosti u Krivoputskoj mikroregiji (3.169 stanovnika, odnosno 35 st. $/ \mathrm{km}^{2}$ ).

Opći porast broja stanovnika krivoputskog područja od sredine 19. stoljeća do Prvoga svjetskog rata posljedica je visokog prirodnog prirasta u uvjetima demografske tranzicije ${ }^{3}$ koja je bila temeljno obilježje njegova demografskog razvoja u tom razdoblju. To potkrjepljuju i pokazatelji o prirodnom kretanju na području bivše općine (današnjeg Grada) Senja početkom 20. stoljeća (Tab. 1.).

Tablica 1: Prosječne stope prirodnog kretanja stanovništva na području bivšse općine (do 1992. godine), odnosno današnjeg Grada Senja početkom 20. stoljeća

\begin{tabular}{|c|c|c|c|c|c|c|}
\hline Prostorna cjelina & \multicolumn{6}{|c|}{$\begin{array}{c}\text { R a z d o b lj e - G o d i n a } \\
\text { Prosječna stopa }((\%)\end{array}$} \\
\hline \multirow{3}{*}{$\begin{array}{l}\text { Općina/Grad } \\
\text { Senj }\end{array}$} & \multicolumn{3}{|c|}{ 1901.-1905. } & \multicolumn{3}{|c|}{1910.} \\
\hline & Rodnost & Smrtnost & Prirast & Rodnost & Smrtnost & Prirast \\
\hline & 42,1 & 30,6 & 11,5 & 38,6 & 22,5 & 16,1 \\
\hline
\end{tabular}

Izvor: 1.

Tablica 2: Broj stanovnika i indeks promjene broja stanovnika Krivoputske mikroregije po popisnim godinama 1857.-2001.

\begin{tabular}{|c|c|c|}
\hline Godina & Broj stanovnika & $\begin{array}{c}\text { Indeks promjene } \\
(1857 .=100,0)\end{array}$ \\
\hline 1857. & 2.545 & - \\
\hline 1869. & 2.645 & 103,9 \\
\hline 1880. & 2.921 & 114,8 \\
\hline 1890. & 2.889 & 113,5 \\
\hline 1900. & 2.707 & 106,4 \\
\hline 1910. & 3.169 & 124,5 \\
\hline 1921. & 2.780 & 109,2 \\
\hline 1931. & 2.582 & 101,5 \\
\hline 1948. & 2.443 & 96,2 \\
\hline 1953. & 2.249 & 88,4 \\
\hline 1961. & 1.799 & 70,7 \\
\hline 1971. & 1.073 & 42,2 \\
\hline 1981. & 591 & 13,2 \\
\hline 1991. & 483 & 19,0 \\
\hline 2001. & 495 & 19,4 \\
\hline & \multicolumn{2}{|}{} \\
\hline
\end{tabular}

Izvor: 2, 3, 4 .

2 Iskazano demografsko smanjenje 1880.-1900. (- 5.596 stanovnika) rezultat je kumulativnog utjecaja više čimbenika, prije svega intenzivnog egzodusa stanovništva u uvjetima agrarne prenaseljenosti, odnosno niske nosivosti krške prirodne osnove, što se u razdoblju velike ekonomske krize 1873.-1895. manifestiralo kroz problem elementarne prehrane stanovništva (pasivni krajevi). U takvim oklonostima stanovništvo krivoputskog područja masovno se uključilo u iseljavanje prema tadašnjim glavnim migracijskim odredištima. Krajem 19. i početkom 20. stoljeća to su, prije svega, bile prekomorske zemlje, čemu je znatno pridonijela uspostava parobrodarskih linija, proširena mreža agencija i kredit za odlazak preko oceana (Holjevac 1967:25, 29). Drugo odredište bile su zemlje zapadne Europe, treće ravničarska područja Hrvatske, a manje i druge zemlje jugoistočne Europe (usp. Rajković 2008:97).

3 Demografska tranzicija teorija je etapnog prijelaza prirodnog kretanja stanovništva pod utjecajem društveno-gospodarskog razvitka s visokih stopa rodnosti i smrtnosti na niske stope rodnosti i smrtnosti, odnosno korjenitog preobražaja režima reprodukcije stanovništva (s neracionalne reprodukcije na racionalnu). U okviru takvog demografskog 
Nakon toga počinje kontinuirana, a povremeno i veoma intenzivna, depopulacija koja je trajala do početka 1990-ih godina, dok je u posljednjem desetljeću 20. stoljeća ponovo zabilježen manji porast broja stanovnika (Tab. 2).

Kao rezultat depopulacije, do početka 1990-ih godina broj stanovnika Krivoputske mikroregije smanjio se za oko $85 \%$, odnosno na samo $15,2 \%$ od njihova broja iz 1910 . godine. Za usporedbu, broj stanovnika Grada Senja istovremeno se smanjio za 45\%, odnosno na razinu od 55,0\% njihova broja iz 1910. godine. Iskazane razlike u dinamici broja stanovnika odražavaju razmjerno nepovoljan položaj Krivoputske regije, kao izrazite ruralne periferije, u prostornim odnosima unutar područja Grada Senja.

Do početka 1960.-ih godina, temeljni uzrok depopulacije Krivoputske mikroregije bilo je iseljavanje stanovništva. Podrobnija analiza pulsiranja depopulacije pokazuje da su apsolutno i relativno najdublje «depopulacijske brazde» zabilježene u razdoblju 1910.-1931. i 1953.-1981., što posredno upućuje i na odgovarajuće potisne i privlačne faktore iseljavanja (Tab. 3).

Tablica 3: Promjena broja stanovnika Krivoputske mikroregije po medupopisnim razdobljima 1957.-2001.

\begin{tabular}{|c|c|c|c|c|}
\hline \multirow{2}{*}{ Razdoblje } & \multicolumn{2}{|c|}{ Ukupna promjena } & \multicolumn{2}{c|}{ Prosječna godišnja promjena } \\
\cline { 2 - 5 } & Aps. & $\%$ & Aps. & $\%$ \\
\hline $1857 .-1869$. & 100 & 3,9 & 8 & 0,33 \\
\hline $1869 .-1880$. & 276 & 10,4 & 25 & 0,95 \\
\hline $1880 .-1890$. & -32 & $-1,1$ & -3 & $-0,11$ \\
\hline $1890 .-1900$. & -182 & $-6,3$ & -18 & $-0,63$ \\
\hline $1900 .-1910$. & 462 & 17,1 & 46 & 1,71 \\
\hline $1910 .-1921$. & -389 & $-12,3$ & -35 & $-1,12$ \\
\hline $1921 .-1931$. & -198 & $-7,1$ & -20 & $-0,71$ \\
\hline $1931 .-1948$. & -138 & $-5,4$ & -8 & $-0,32$ \\
\hline $1948 .-1953$. & -194 & $-7,9$ & -11 & $-0,46$ \\
\hline $1953 .-1961$. & -450 & $-20,0$ & -56 & $-2,50$ \\
\hline $1961 .-1971$. & -726 & $-40,4$ & -73 & $-4,04$ \\
\hline $1971 .-1981$. & -482 & $-44,9$ & -48 & $-4,49$ \\
\hline $1981 .-1991$. & -108 & $-18,3$ & -11 & $-1,83$ \\
\hline $1991 .-2001$. & 12 & 2,5 & 1 & 0,25 \\
\hline
\end{tabular}

Između dvaju svjetskih ratova iseljavanje se odvijalo pod naglašenim utjecajem ograničenih mogućnosti tradicionalnog gospodarstva da osigura egzistenciju prekobrojnog stanovništva. Do 1930. godine najveći je broj iseljenika odlazio u prekomorske zemlje, prije svega u SAD, ali je nakon uvođenja useljeničkih kvota, porastao interes za zapadnoeuropske zemlje. Pored zapošljavanja u inozemstvu, značajan broj Krivopućana u međuratnom je razdoblju iseljavao u ravničarske dijelove Hrvatske gdje su nastavljali sa sličnim obrascem socijalno-gospodarskog života, ali u znatno povoljnijim egzistencijalnim uvjetima nego u starom kraju. Reprezentativan primjer takvih unutarnjih migracija predstavljaju primorski Bunjevci Krivopućani na području Virovitice, čije je cikličko naseljavanje i prilagodba uvjetima života u novoj sredini detaljno obrađeno i prezentirano u prvom svesku Monografije (Rajković 2008:79-94, RajkovićJurković 2008:95-119).

Drugi veliki val mehaničkog odljeva stanovništva iz Krivoputske mikroregije odnosi se na razdoblje poslije Drugoga svjetskog rata, s težištem na 1960-im godinama. Tadašnje iseljavanje sastavni je dio široko pokrenutog procesa socijalno-prostorne pokretljivosti stanovništva Hrvatske koje se odvijalo između

prijelaza izdvajaju se tri etape: 1 . predtranzicijska (visoka stopa rodnosti i smrtnosti i promjenljiv ali uglavnom uravnotežen prirast), 2. tranzicijska etapa s tri podetape: a) ranom (visoke stope rodnosti, smanjivanje smrtnosti, porast prirasta stanovništva), b) zrelom (visoke stope rodnosti, brzo smanjivanje smrtnosti, ekspanzija prirasta) i c) kasnom (niska stopa smrtnosti, smanjivanje rodnosti, smanjivanje prirasta) te 3. poslijetranzicijska etapa (niske i uravnotežene stope rodnosti i smrtnosti, nulta stopa prirasta ili prirodni pad stanovništva). Više o tome u: Wertheimer-Baletić, A., Stanovništvo i razvoj, Mate, Zagreb, 1999. 
Tablica 4: Opíe keretanje stanovnistva Krivoputske mikroregije 1961. - 2001. godine.

\begin{tabular}{|c|r|r|r|r|r|r|r|}
\hline \multirow{2}{*}{ Razdoblje } & \multicolumn{2}{c}{ Promjena } & \multicolumn{2}{c}{$\begin{array}{c}\text { Prirodno } \\
\text { broja stan. }\end{array}$} & \multicolumn{2}{c|}{$\begin{array}{c}\text { Selidbeni } \\
\text { saldo }\end{array}$} & \multicolumn{2}{c|}{$\begin{array}{c}\text { Tip kretanja } \\
\text { stanovništva* }\end{array}$} \\
\cline { 2 - 6 } & Aps. & \multicolumn{1}{c}{$\%$} & Aps. & $\%$ & Aps. & $\%$ & \\
\hline $1961 .-1971$. & -726 & $-40,4$ & -30 & $-1,7$ & -696 & $-38,7$ & $\mathrm{E}^{4}$ \\
\hline $1971 .-1981$. & -476 & $-44,4$ & -52 & $-4,8$ & -424 & $-39,5$ & $\mathrm{E}^{4}$ \\
\hline $1981 .-1991$. & -114 & $-19,1$ & -76 & $-12,7$ & -38 & $-6,4$ & $\mathrm{E}^{4}$ \\
\hline $1991 .-2001$. & 12 & 2,5 & -53 & $-11,0$ & 65 & 13,5 & $\mathrm{I}^{3}$ \\
\hline
\end{tabular}

Izvor: 3, 4, 5 .

* Tipovi općeg kretanja stanovništva (prema: Friganović 1990:102): E 4- Demografsko izumiranje, I’3 - Slaba regeneracija imigracijom.

slabije razvijenih ruralnih područja i gradova kao središta složenijega socijalno-gospodarskog života. U okviru toga, modernog, iseljavanja samo tijekom dva desetljeća 1961.-1981. godine s tog područja iselilo je 1.120 stanovnika, odnosno čak 62,3\% od ukupnog broja stanovnika iz 1961. godine. (Tab. 4).

Glavno emigracijsko odredište stanovništva Krivoputske mikroregije bilo je najbliže gradsko središte - Senj, a od makroregionalnih središta - Rijeka. Temeljni motiv njihova preseljavanja bili su školovanje i zapošljavanje. Zbog blizine (oko 14 kilometara) i lakše dostupnosti, pritom je prevladavalo preseljavanje u Senj u kojem, prema nekim procjenama, danas živi oko 80\% Krivopućana (Rajković 2008:85-86).

Dugotrajno, a povremeno i veoma intenzivno iseljavanje pretežno mladog i mlađeg stanovništva ostavilo je duboki trag u narušenoj biološkoj (dobno-spolnoj) strukturi, a posljedično i negativnom prirodnom kretanju stanovništva (denatalitetu). To se neposredno odrazilo u sve nepovoljnijim obilježjima općeg kretanja stanovništtva tog ekzodusnog prostora. Ono je već sredinom prošlog stoljeća pripadalo tipu E ${ }^{3}$ s trendom izrazite depopulacije, a već od početka 1960-ih godina $\mathrm{E}^{4}$ kojeg karakterizira negativno prirodno kretanje i negativno popisom ustanovljeno kretanje, pri čemu je stopa prirodnog kretanja (smanjenja), manja od stope popisom ustanovljenog smanjenja, te trend demografskog izumiranja (usp. Friganović 1990:100-102). Takav trend općeg kretanja stanovništva - demografsko izumiranje - nastavio se 1970-ih i 1980-ih godina, praćen sve većim negativnim intenzitetom prirodnog kretanja (denataliteta).

Utoliko više iznenađuju statistički pokazatelji općeg kretanja stanovništva Krivoputske mikroregije, prema kojima promatrani prostor u posljednjem međupopisnom razdoblju, 1991.-2001., pripada tipu I ${ }^{3}$ $s$ trendom slabe regeneracije imigracijom, za što međutim nema uporišta u prostornoj stvarnosti. Objaš-

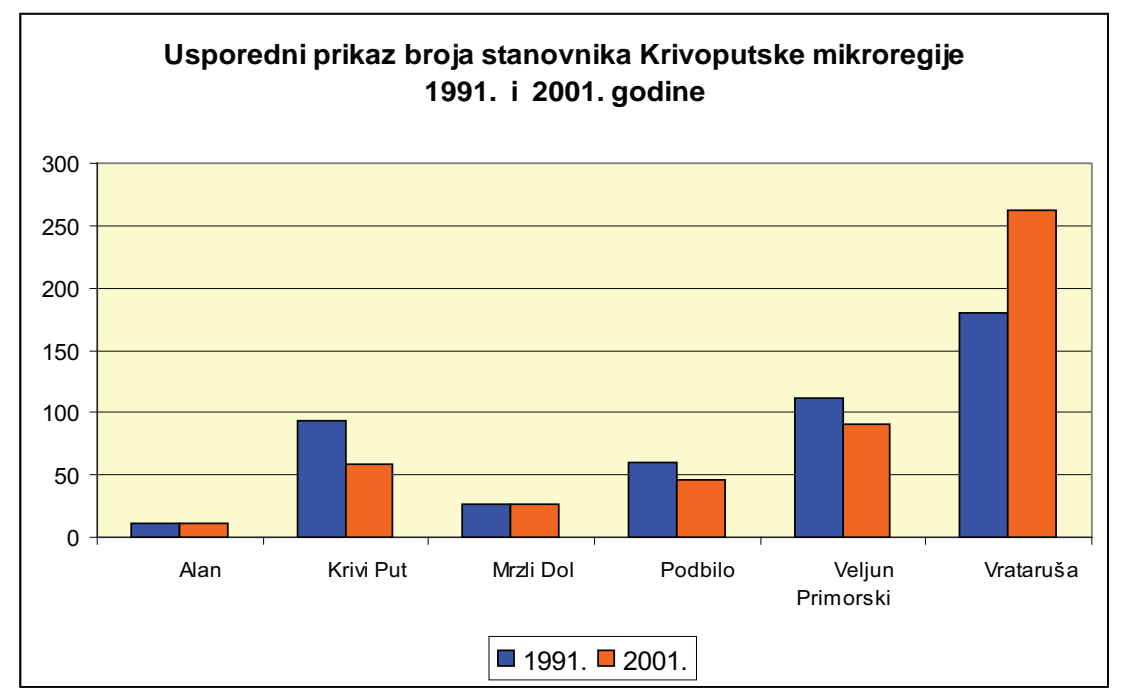

Izvor: 3,4 .

Slika 1: Promjena broja stanovnika u naseljima Krivoputske mikroregije 1991.-2001. godine. 
njenje je, u statistički utvrđenom, demografskom porastu naselja Vrataruša za 82 stanovnika, odnosno 45,6\% prema broju njegovih stanovnika iz 1991. godine, po čemu je to jedino takvo naselje u promatranom prostoru. Pritom, također, treba napomenuti da dva naselja bilježe stagnantno kretanje broja stanovnika (saldo 0), ali riječ je o patuljastom (Alan, 11 stanovnika) i malom naselju (Mrzli Dol, 27 stanovnika), dok su ostala naselja mikroregije zabilježila više-manje izrazitu depopulaciju (sl. 1..).

Svojim položajem i funkcijama, Vrataruša se umnogome izdvaja u odnosu na ostala naselja Krivoputske mikroregije. To je jedino naselje promatranog prostora čiji statistički definiran teritorij participira u obalnom pojasu, 4-5 km zračne udaljnosti između naselja Senj na jugu i Sibinj Krmpotski na sjeveru. Zbog blizine i dostupnosti Senja, od početka 1980-ih godina na tom dijelu obale započela je dinamičnija građevinska djelatnost i doseljavanje stanovništva, mahom ranijih iseljenika iz gornjačkih naselja Krivoputske mikroregije. Na taj način u dvadesetgodišnjem razdoblju 1981.-2001., broj stanovnika naselja gotovo se udvostručio (sa 135 stanovnika 1981. na 262 stanovnika 2001.). Širenjem građevinske strukture i uključivanjem pridošlog stanovništva u socijalno-gospodarski život Senja, priobalni dio Vrataruše posljednjih se desetljeća sve više razvija kao prigradsko naselje. $S$ druge pak strane, u tom pojasu smještene su dvije uvale - Bunica (auto-kamp) i Jelena, čija je turistička valorizacija potakla izgradnju kuća za odmor, odnosno turističku djelatnost (apartmani), uz trasu državne ceste (Magistrale). ${ }^{4}$ Određeni broj vlasnika (ili članova kućanstva) takvih kuća za odmor iz spekulativnih razloga prikazuje Vratarušu kao mjesto stalnog boravka, iako u tom naselju borave samo sezonski, ${ }^{5}$ što je dodatno pridonijelo, ali ne i presudno utjecalo da opće kretanje stanovništva 1991.-2001. u tom naselju pripada tipu $\mathrm{I}^{3}$ s trendom - slaba regeneracija imigracijom.

Za razliku od Vrataruše, opće kretanje stanovništva u gornjačkim naseljima ima suprotan predznak. U prilog tome svjedoči podatak da, poslije Vrataruše, tri najveća naselja u mikroregiji - Veljun Primorski (91 stanovnik), Krivi Put (58 stanovnika) i Podbilo (46 stanovnika) u posljednjem međupopisnom razdoblju karakterizira tip $\mathrm{E}^{4} \mathrm{~s}$ trendom - demografsko izumiranje. Doda li se tome, da istom tipu kretanja stanovništva pripada i područje Grada Senja, ali i Ličko-senjska županija u cjelini, tada se opravdano nameće pitanje o realnim mogućnostima demografske revitalizacije ovog dijela Hrvatske.

\section{STRUKTURA STANOVNIŠTVA}

Struktura stanovništva funkcija je prirodnog i mehaničkog kretanja, ali je istovremeno i njegov činitelj. Stoga sastav stanovništva treba promatrati u uzročno-posljedičnoj vezi s dinamikom stanovništva.

Iseljavanjem stanovništva, pretežno mlađih dobnih skupina, mijenjala su se i strukturna obilježja stanovništva Krivoputske regije. To se neposredno odrazilo u kontinuiranom smanjivanju udjela mladih i porastu udjela stanovništva starijih dobnih skupina, odnosno u intenzivnom procesu starenja. Struktura stanovništva po dobi temeljna je osobina sastava stanovništva jer pokazuje potencijalnu vitalnost i biodinamiku stanovništva nekog prostora. U teoriji se razlikuju tri tipa dobnog sastava stanovništva: mlada, zrela i stara populacija. Mladim stanovništvom smatra se ono u kojem skupina do 19 godina čini više od $35 \%$ ukupne populacije, dok se starim smatra ono u kojem skupina od 60 i više godina čini više od 12\% ukupnog stanovništva. Zrela je populacija ona koja nema izrazite značajke ni mladog ni starog stanovništva (Friganović 1990:112).

Analiza dobnog sastava stanovništva Krivoputske mikroregije pokazuje uznapredovali proces demografskog starenja. Prema popisu 2001. godine, udio starog stanovništva iznosio je čak 30\%, a dobni sastav pripadao je tipu 6 s obilježjem «izrazito duboka starost». Iako isti tip dobnog sastava karakterizira i Grad

4 O motivu gradnje i dinamici građevinskih aktivnosti u priobalnom pojasu Vrataruše svjedoče podaci da je 1971. u tom naselju ukupno registrirano 66 stanova, među kojima niti jedan za odmor, 1981. godine 62 stana, od kojih niti jedan za odmor, 1991. godine 121 stan, od kojih 61 za stalno stanovanje i 61 za odmor, dok je 2001. registrirano 190 stanova, od kojih 129 za stalno stanovanje i 61 za odmor.

5 Riječ je o općepoznatom fenomenu diljem hrvatskog dijela Jadrana; da bi izbjegli plaćanje poreza i prireza na dohodak, vlasnici apartmana ili pojedini članovi njihovih obitelji prijavljuju stalni boravak u turističkom mjestu gdje imaju kuće za odmor. 
Tablica 5: Dobni sastav i tip stanouništva prema indeksu starosti Krivoputske mikeroregije po naseljima 2001. godine.

\begin{tabular}{|c|c|c|c|c|c|c|c|}
\hline \multirow{2}{*}{$\begin{array}{l}\text { Prostorna } \\
\text { cjelina }\end{array}$} & \multirow{2}{*}{$\begin{array}{c}\text { Broj } \\
\text { stanovnika }\end{array}$} & \multicolumn{3}{|c|}{ Dobni sastav stanovništva } & \multirow{2}{*}{$\begin{array}{c}\text { Udio } \\
\text { starog } \\
\text { stanovništva }\end{array}$} & \multirow{2}{*}{$\begin{array}{l}\text { Indeks } \\
\text { starosti }\end{array}$} & \multirow{2}{*}{$\begin{array}{c}\text { Tip stanovništva } \\
\text { prema } \\
\text { dobnom sastavu* }\end{array}$} \\
\hline & & $\begin{array}{l}\text { Mladi } \\
(<19)\end{array}$ & $\begin{array}{c}\text { Zreli } \\
(20-59)\end{array}$ & $\begin{array}{l}\text { Stari } \\
(>60)\end{array}$ & & & \\
\hline Grad Senj & 8134 & 1664 & 4345 & 2125 & 26,1 & 127,7 & 6 \\
\hline Krivoputska mikroregija & 495 & 104 & 244 & 147 & 29,7 & 141,3 & 6 \\
\hline - Alan & 11 & 2 & 8 & 1 & 9,1 & 50,0 & 4 \\
\hline - Krivi Put & 58 & 11 & 20 & 27 & 46,6 & 245,5 & 6 \\
\hline - Mrzli Dol & 27 & 4 & 9 & 14 & 51,9 & 350,0 & 6 \\
\hline - Podbilo & 46 & 5 & 20 & 21 & 45,7 & 420,0 & 6 \\
\hline - Veljun Primorski & 91 & 19 & 33 & 39 & 42,9 & 205,3 & 6 \\
\hline - Vrataruša & 262 & 63 & 154 & 45 & 17,2 & 71,4 & 5 \\
\hline
\end{tabular}

* Tipovi dobnog sastava stanovništva (prema: Nejašmić 2008:153)

4 - duboka starost, 5 - vrlo duboka starost, 6 - izrazito duboka starost Izvor: 6 .

Senj, osjetno veći udio starog stanovništva i veći indeks starosti pokazuju znatno veći stupanj ostarjelosti stanovništva te periferne ruralne mikroregije od prosjeka jedinice lokalne samouprave (Tab. 5).

Podrobnija analiza procesa starenja, po naseljima, pokazuje da najmanje staro stanovništvo ima Alan, a potom i Vrataruša. Kad je riječ o Alanu, to je samo još jedna potvrda pravila o atipičnim obilježjima patuljastih naselja, dok je u slučaju Vrataruše to rezultat imigracije pretežno zrelog stanovništva od početka 1980-ih godina. S druge pak strane, najnepovoljniji indeks starosti karakterizira "gornjačka naselja» Podbilo, Mrzli Dol i Krivi Put, pri čemu se dobni sastav stanovništva Podbila sasvim približio posljednjem i najnepovoljnijem tipu dobnog sastava -7 s obilježjem «krajnje duboka starost» (Sl. 2).

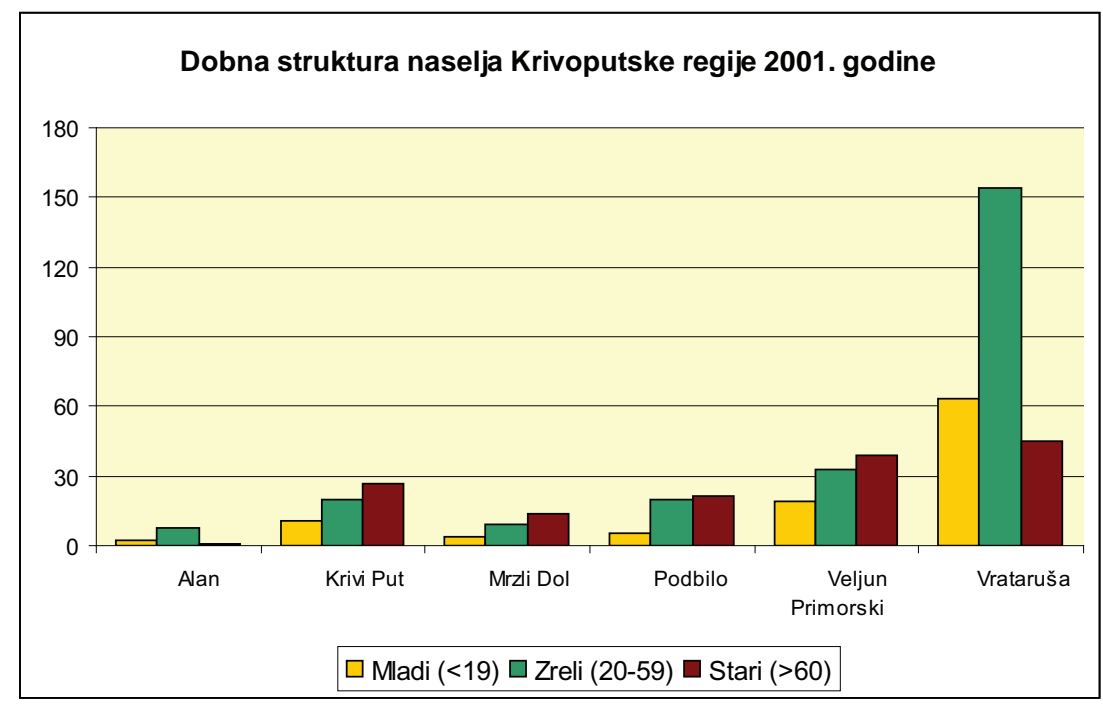

Slika 2: Dobna struktura u naseljima Krivoputske mikroregije 2001. godine

Izvor: 6.

Pored negativnog utjecaja na reprodukciju stanovništva, što se izravno odražava u sve većem denatalitetu, poodmakao proces starenja neposredno utječe i na gospodarski i socijalni život krivoputskog prostora. Promjene u dobnom sastavu stanovništva zakonito prate i negativne promjene u mentalitetu, odnosno sustavu vrijednosti, pojedinca i društvene zajednice. To se, između ostaloga, manifestira i u 
opadanju razine optimizma i slabljenju poduzetničkog duha. U takvim okolnostima, ne samo što su sve slabije mogućnosti za gospodarsku revitalizaciju, nego je i teško uspostaviti zadovoljavajući i uravnotežen socijalni život.

Pored dobnog sastava, najvažnija demografska struktura nedvojbeno je sastav stanovništva prema školskoj spremi. Ta struktura pokazatelj je opće razvijenosti društvene zajednice promatranog prostora i odražava osposobljenost njezina stanovništva za složeniji društveno-gospodarski razvoj, kao sastavni dio modernizacijskih procesa.

Kao ruralna periferija, Krivoputska mikroregija ističe se nepovoljnijom obrazovnom strukturom stanovništva u odnosu na prosjek Grada Senja. To se, prije svega, očituje u podatku da je otprilike trećina od ukupnog broja njezinih stanovnika starijih od 15 godina 2001. godine bilo bez škole, odnosno s nezavršenom osnovnom školom, dok je u Gradu Senju njihov udio bio manji od petine ukupnog stanovništva. Najnepovoljnijim obrazovnim sastavom među naseljima promatranog prostora ističu se Veljun Primorski, s gotovo dvije trećine stanovništva bez škole is nezavršenom osnovnom školom, te Krivi Put, s oko 55\% stanovništva u toj obrazovnoj kategoriji.

$S$ druge pak strane, ovo područje ima veći udio stanovnika s višom i visokom stručnom spremom od prosjeka Grada. O čemu se zapravo radi? Taj prividni paradoks moguće je razumjeti jedino uz pomoć tabelarne analize apsolutnih i relativnih pokazatelja obrazovnog sastava stanovništva (Tab. 6 i Tab. 7).

Tablica 6: Stanovništvo Krivoputske mikroregije staro 15 i više godina prema završenoj školi 2001. godine.

\begin{tabular}{|c|c|c|c|c|c|c|c|}
\hline \multirow[b]{2}{*}{$\begin{array}{c}\text { Prostorna } \\
\text { cjelina }\end{array}$} & \multicolumn{6}{|c|}{ Školska sprema } & \multirow[b]{2}{*}{ Nepoz. } \\
\hline & $\begin{array}{c}\text { Stanovništvo } \\
\text { starije } \\
\text { od } 15 \text { god. }\end{array}$ & $\begin{array}{c}\text { Bez škole } \\
\text { i nezavršena } \\
\text { osn. škola }\end{array}$ & $\begin{array}{c}\text { Osnovna } \\
\text { škola }\end{array}$ & $\begin{array}{l}\text { Srednja } \\
\text { škola }\end{array}$ & $\begin{array}{l}\text { Viša/ } \\
\text { visoka }\end{array}$ & $\begin{array}{l}\text { Znanstveni } \\
\text { stupanj }\end{array}$ & \\
\hline Grad Senj & 4687 & 864 & 873 & 2458 & 444 & 10 & 38 \\
\hline Krivoputska mikroregija & 410 & 134 & 47 & 170 & 48 & $\mathbf{0}$ & 11 \\
\hline - Alan & 9 & 1 & 1 & 7 & 0 & 0 & 0 \\
\hline - Krivi Put & 49 & 27 & 5 & 12 & 0 & 0 & 5 \\
\hline - Mrzli Dol & 23 & 11 & 2 & 6 & 0 & 0 & 4 \\
\hline - Podbilo & 43 & 16 & 6 & 17 & 4 & 0 & 0 \\
\hline - Veljun Primorski & 73 & 47 & 7 & 18 & 1 & 0 & 0 \\
\hline - Vrataruša & 213 & 32 & 26 & 110 & 43 & 0 & 2 \\
\hline
\end{tabular}

Izvor: 7.

Tablica 7: Obrazouni sastav stanounistva Krivoputske mikroregije po naseljima 2001. godine.

\begin{tabular}{|c|c|c|c|c|c|c|c|}
\hline \multirow[b]{2}{*}{$\begin{array}{c}\text { Prostorna } \\
\text { cjelina }\end{array}$} & \multicolumn{6}{|c|}{ Školska sprema } & \multirow[b]{2}{*}{$\begin{array}{c}\text { Nepoz. } \\
(\%) \\
\end{array}$} \\
\hline & $\begin{array}{l}\text { Stanovništvo } \\
\text { starije } \\
\text { od } 15 \text { god. } \\
\text { (aps.) }\end{array}$ & $\begin{array}{c}\text { Bez škole } \\
\text { i nezavršena } \\
\text { osn. škola } \\
(\%)\end{array}$ & $\begin{array}{c}\text { Osnovna } \\
\text { škola } \\
(\%)\end{array}$ & $\begin{array}{c}\text { Srednja } \\
\text { škola } \\
(\%)\end{array}$ & $\begin{array}{c}\text { Viša/ } \\
\text { visoka } \\
(\%)\end{array}$ & $\begin{array}{c}\text { Znanstveni } \\
\text { stupanj } \\
(\%)\end{array}$ & \\
\hline Grad Senj & 4687 & 18,4 & 18,6 & 52,4 & 9,5 & 0,2 & 0,8 \\
\hline Krivoputska mikroregija & 410 & 32,7 & 11,5 & 41,5 & 11,7 & 0,0 & 2,7 \\
\hline - Alan & 9 & 11,1 & 11,1 & 77,8 & 0,0 & 0,0 & 0,0 \\
\hline - Krivi Put & 49 & 55,1 & 10,2 & 24,5 & 0,0 & 0,0 & 10,2 \\
\hline - Mrzli Dol & 23 & 47,8 & 8,7 & 26,1 & 0,0 & 0,0 & 17,4 \\
\hline - Podbilo & 43 & 37,2 & 14,0 & 39,5 & 9,3 & 0,0 & 0,0 \\
\hline - Veljun Primorski & 73 & 64,4 & 9,6 & 24,7 & 1,4 & 0,0 & 0,0 \\
\hline - Vrataruša & 213 & 15,0 & 12,2 & 51,6 & 20,2 & 0,0 & 0,9 \\
\hline
\end{tabular}


Kao što je moguće uočiti, odgovor leži u podatku da je, oko $90 \%$ od ukupnog broja stanovnika krivoputskog kraja, koncentrirano u naselju Vrataruša, pri čemu je opravdano pretpostaviti - u njegovu priobalnom dijelu. Obzirom da je riječ o dijelu naselja koji je funkcionalno i fizionomski potpuno integriran u okviru proširene gradske aglomeracije Senja, realniju sliku o obrazovnom sastavu stanovništva Krivoputske mikroregije, odnosno stupnju zaostajanja za prosjekom Grada, moguće je dobiti njegovim izuzimanjem iz promatrane prostorne cjeline.

Obrazovna struktura stanovništva u uskoj je, uzročno-posljedičnoj vezi s društveno-gospodarskim razvojem promatranog prostora. Temeljne karakteristike tog razvoja zrcale se iz sastava stanovništva prema gospodarskoj aktivnosti i gospodarskim djelatnostima. Pritom udio aktivnog u ukupnom stanovništvu pokazuje razinu aktivnosti (što je veća ekonomska razvijenost, to je viši udio aktivnog stanovništva), dok socijalno-ekonomska struktura pokazuje dosegnuti stupanj preobrazbe u tranziciji, iz tradicionalnog u moderno društvo.

Analiza indikatora aktivnosti i zaposlenosti pokazuje da po stopi aktivnosti Krivoputska mikroregija neznatno zaostaje za prosjekom Grada Senja, dok je po stopi zaposlenosti gotovo izjednačena s prosjekom matične jedinice lokalne samouprave (Tab. 8).

Tablica 8: Aktivnost i zaposlenost Krivoputske mikroregije po naselima 2001. godine.

\begin{tabular}{|c|r|r|r|r|r|}
\hline \multirow{2}{*}{$\begin{array}{c}\text { Prostorna } \\
\text { cjelina }\end{array}$} & \multicolumn{1}{c|}{$\begin{array}{c}\text { Ukupno } \\
\text { stanovništvo } \\
\text { 2001. }\end{array}$} & \multicolumn{1}{|c|}{ Aktivno stanovništvo } & \multicolumn{2}{|c|}{ Zaposleno stanovništvo } \\
\cline { 5 - 7 } & & $\begin{array}{c}\text { Udio u } \\
\text { ukup.st. }\end{array}$ & Aps. & $\begin{array}{c}\text { Udio u } \\
\text { aktiv.st. }\end{array}$ \\
\hline Grad Senj & $\mathbf{8 1 3 4}$ & $\mathbf{3 3 5 0}$ & $\mathbf{4 1 , 2}$ & $\mathbf{2 . 1 7 3}$ & $\mathbf{6 4 , 9}$ \\
\hline Krivoputska mikroregija & $\mathbf{4 9 5}$ & $\mathbf{1 9 4}$ & $\mathbf{3 9 , 2}$ & $\mathbf{1 2 5}$ & $\mathbf{6 4 , 4}$ \\
\hline - Alan & 11 & 5 & 45,5 & 4 & 80,0 \\
\hline - Krivi Put & 58 & 12 & 20,7 & 5 & 41,7 \\
\hline - Mrzli Dol & 27 & 18 & 66,7 & 3 & 16,7 \\
\hline - Podbilo & 46 & 15 & 32,6 & 11 & 73,3 \\
\hline - Veljun Primorski & 91 & 23 & 25,3 & 14 & 60,9 \\
\hline - Vrataruša & 262 & 121 & 46,2 & 88 & 72,7 \\
\hline
\end{tabular}

Izvor: 8.

Pritom među naseljima mikroregije postoje izrazite razlike u stopi aktivnosti, s rasponom između najnižih vrijednosti Krivoga Puta i Veljuna Primorskog s jedne, do Mrzloga Dola i Vrataruše s druge strane. Obzirom da najnižu stopu aktivnosti bilježe dva, poslije Vrataruše, najveća naselja tog dijela Grada Senja, to sugerira potrebu osnaživanja funkcije rada u naseljima gornjačkog pojasa, prije svega Krivome Putu kao njegovu nominalnom središtu. Iz podatka da $62,4 \%$ od ukupnog broja aktivnih, odnosno 70,4\% zaposlenih stanovnika Krivoputske mikroregije otpada na naselje Vratarušu (priobalni dio naselja), te da se najvišom stopom zaposlenosti ističu gornjačka naselja na županijskoj cesti, Alan i Podbilo, nameće se zaključak da temeljno značenje za razvoj aktivnosti i zaposlenosti u pojedinim naseljima imaju blizina i dostupnost središta rada (Sl. 3).

Dok kod Vrataruše, kao prigradskog «cestovnog» naselja, takvo uopćavanje nije sporno, u slučaju navedenih gornjačkih naselja treba biti oprezniji jer je riječ o naseljima s malim brojem stanovnika, što podrazumijeva i «ekonomiju malih razmjera» koja je nerijetko otklon od uopćene zakonitosti. Upravo je to slučaj s Alanom u kojem se nalazi manji obiteljski pogon aluminijske i PVC stolarije. Slično je i u Veljunu Primorskom jer se tamo nalazi manja farma krava. To znači da većina (Alan) ili znatan dio (Veljun) od njihovih malobrojnih aktivnih stanovnika nisu uključeni u dnevne migracije prema središtima rada. ${ }^{6}$

$\overline{6}$ Postojanje takvih proizvodnih pogona u perifernim i prometno slabije povezanim naseljima u pravilu se odražava i u organizaciji obiteljskog života. Muškarci, nositelji proizvodne djelatnosti, žive i rade u gornjačkim naseljima, a žene s djecom (koja pohađaju školu) preko tjedna borave u središnjim naseljima (Rijeci, Senju), tako da je obitelj na okupu vikendom (Izvor: usmeni iskaz Marijete Rajković, zasnovan na terenskom istraživanju). 


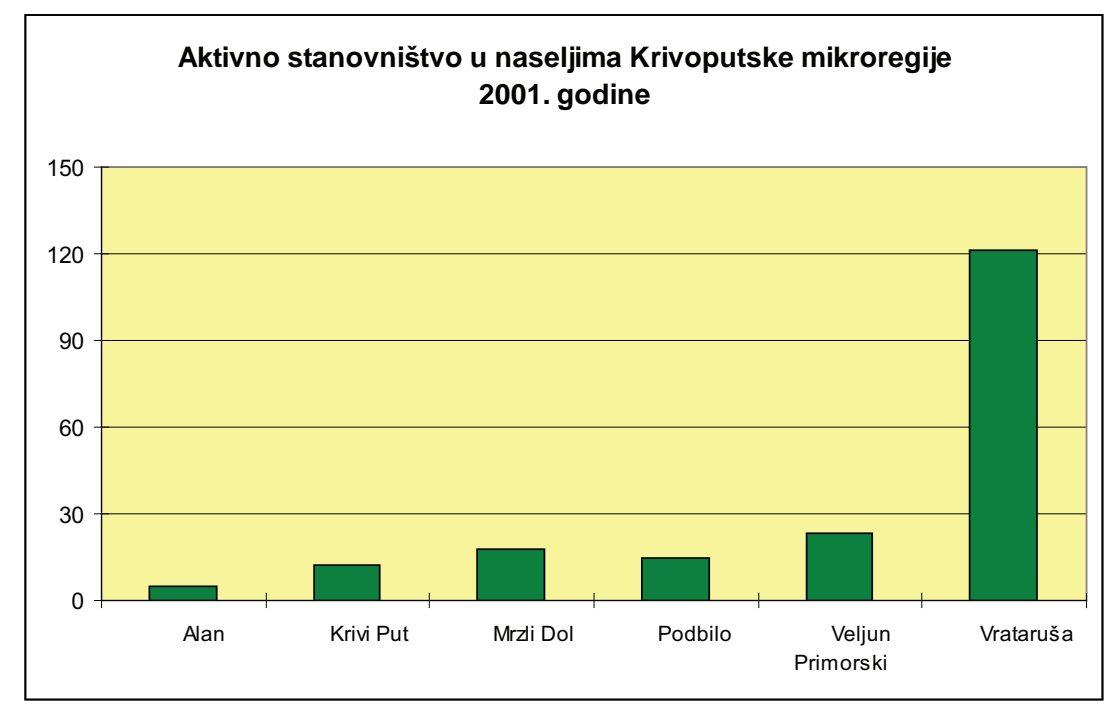

Slika 3: Aktivno stanounistvo u naselima Krivoputske mikroregije 2001. godine.

Izvor: 8 .

Kako složeniji gospodarski razvoj prati socijalno prestrukturiranje stanovništva tradicionalnih područja (deagrarizacija), jedan je od važnih pokazatelja dosegnutog stupnja razvoja i preobrazbe društvenogospodarske strukture udio poljoprivrednika u ukupnom stanovništvu, a pogotovo aktivnog poljoprivrednog, u ukupno aktivnom stanovništvu. Provedena tabelarna analiza broja i udjela poljoprivrednika na području Krivoputske mikroregije pokazuje neočekivano mali broj poljoprivrednika i razmjerno marginalno značenje poljoprivrede u gospodarsko-socijalnom životu tog dijela Grada Senja (Tab. 9).

Tablica 9: Poljoprivredno stanounistvo Krivoputske mikroregije po naseljima 2001. godine.

\begin{tabular}{|c|r|r|r|r|}
\hline \multirow{2}{*}{$\begin{array}{c}\text { Prostorna } \\
\text { cjelina }\end{array}$} & \multicolumn{2}{|c|}{$\begin{array}{c}\text { Ukupno poljoprivredno } \\
\text { stanovništvo }\end{array}$} & \multicolumn{2}{c|}{$\begin{array}{c}\text { Aktivno poljoprivredno } \\
\text { stanovništvo }\end{array}$} \\
\cline { 2 - 5 } & Aps & \multicolumn{1}{c|}{ Udio u uk.st. } & \multicolumn{1}{c|}{ Aps. } & Udio u uk.akt.st. \\
\hline Grad Senj & $\mathbf{2 0 7}$ & $\mathbf{2 , 5}$ & $\mathbf{1 0}$ & $\mathbf{0 , 3}$ \\
\hline Krivoputska mikroregija & $\mathbf{1 2}$ & $\mathbf{2 , 4}$ & $\mathbf{1 0}$ & $\mathbf{5 , 2}$ \\
\hline - Alan & 0 & 0,0 & 0 & 0,0 \\
\hline - Krivi Put & 1 & 1,7 & 1 & 8,3 \\
\hline - Mrzli Dol & 0 & 0,0 & 0 & 0,0 \\
\hline - Podbilo & 3 & 6,5 & 3 & 20,0 \\
\hline - Veljun Primorski & 4 & 4,4 & 3 & 13,0 \\
\hline - Vrataruša & 4 & 1,5 & 3 & 2,5 \\
\hline
\end{tabular}

Izvor: 9.

Iz izloženih podataka jasno proizlazi da preostali, mali broj poljoprivrednika (ukupno 12, od čega 10 aktivnih), od kojih je većina u staroj dobnoj skupini, ne može biti nositelj bilo kakve organizirano zasnovane poljoprivredne proizvodnje. Neovisno o postojećim resursima, sadržanim u prostranim pašnjačkim površinama, na visoravni potkapelske padine, mali broj uglavnom starih stanovnika ograničavajući je čimbenik za njihovu gospodarsku valorizaciju.

Pouzdaniji, sintetički pokazatelj društveno-gospodarske razvijenosti promatranog prostora predstavlja gospodarska struktura, temeljena na udjelu zaposlenih u četiri glavna sektora gospodarske djelatnosti: primarnog, sekundarnog, tercijarnog i kvartarnog. ${ }^{7}$ Iz tipa gospodarske strukture, ovisno o udjelu zapo-

Primarni sektor obuhvaća stanovništvo zaposleno u primarnoj proizvodnji (poljoprivreda, ribarstvo, šumarstvo i vodoprivreda). Sekundarni obuhvaća stanovništvo zaposleno u prerađivačkoj proizvodnji (rudarstvo, industrija, građevi- 
slenih u pojedinom sektoru djelatnosti, moguće je uočiti karakteristične razvojne tendencije u procesu prijelaza iz tradicionalnog u moderno industrijsko i uslužno društvo, odnosno s gospodarstva temeljenog na primarnim djelatnostima (koje karakterizira manja podjela rada i veća ovisnost o prirodnim resursima) na industrijsku proizvodnju (obilježenu većom podjelom rada, tehničkim napretkom, mehanizacijom i racionalizacijom), a potom i uslužne djelatnosti (koje prati veća profesionalna i prostorna mobilnost, te aktivnosti vezane za slobodno vrijeme).

Komparativna analiza broja i udjela zaposlenih po sektorima djelatnosti pokazuje relativno visok udio zaposlenih u primarnom sektoru djelatnosti i Grada Senja i Krivoputske mikroregije. Pritom je višestruko veći udio zaposlenih u primarnom sektoru Grada Senja od državnog prosjeka $(3,1 \%)$ pokazatelj njegova zaostajanja u socijalno-gospodarskom razvoju zemlje. Jednako kao što je i gotovo $40 \%$ veći udio tog sektora u socijalno-ekonomskoj strukturi Krivoputske mikroregije pokazatelj njezina zaostajanja u okviru Grada Senja (Tab. 10 i Tab. 11).

Tablica 10: Stanounistvo Krivoputske regije prema sektorima gospodarskih djelatnosti 2001. godine.

\begin{tabular}{|l|r|r|r|r|r|}
\hline \multirow{2}{*}{ Prostorna cjelina } & \multirow{2}{*}{ Broj zaposlenih } & \multicolumn{4}{|c|}{ S e k t o r i d j e l a t n o s t i } \\
\cline { 3 - 6 } & & I. & \multicolumn{1}{|c|}{ II. } & \multicolumn{1}{c|}{ III. } & \multicolumn{1}{|c|}{ IV. } \\
\hline Grad Senj & 2.173 & 239 & 552 & 829 & 553 \\
\hline Krivoputska mikroregija & 125 & 19 & 24 & 42 & 40 \\
\hline - Naselje Vrataruša & 88 & 8 & 17 & 27 & 36 \\
\hline - Ostala naselja (bez Vrataruše) & 37 & 11 & 7 & 15 & 4 \\
\hline
\end{tabular}

Izvor: 10 .

Tablica 11: Socijalno-ekonomska struktura stanounistva Krivoputske regije 2001. godine.

\begin{tabular}{|l|r|r|r|r|r|}
\hline \multirow{2}{*}{ Prostorna cjelina } & \multirow{2}{*}{ Broj zaposlenih } & \multicolumn{4}{|c|}{ S e k t o r i d j e l a t n o s t i } \\
\cline { 3 - 6 } & & \multicolumn{1}{|c|}{ I. } & \multicolumn{1}{c|}{ II. } & \multicolumn{1}{c|}{ III. } & \multicolumn{1}{c|}{ IV. } \\
\hline Grad Senj & 100,0 & 11,0 & 25,4 & 38,2 & 25,4 \\
\hline Krivoputska mikroregija & 100,0 & 15,2 & 19,2 & 33,6 & 32,0 \\
\hline - Naselje Vrataruša & 100,0 & 9,1 & 19,3 & 30,0 & 40,9 \\
\hline - Ostala naselja (bez Vrataruše) & 100,0 & 29,7 & 18,9 & 40,6 & 10,8 \\
\hline
\end{tabular}

Pravi pokazatelj stupnja zaostajanja Krivoputske regije u odnosu na prosjek Grada vidljiv je tek kad se razdvoje podaci za naselje Vratarušu i ostala naselja mikroregije. Naime, kao propulzivno prigradsko naselje, Vrataruša ima manji udio zaposlenih u primarnom sektoru i osjetno veći udio zaposlenih u kvartarnom sektoru od prosjeka Grada. Za razliku od toga, ostala naselja mikroregije bilježe gotovo trostruko veći udio zaposlenih u primarnom sektoru od prosjeka Grada, što uvjerljivo svjedoči o niskom stupnju preobrazbe u većini gornjačkih naselja.

Iskazane razlike u funkcionalnoj usmjerenosti između Vrataruše i ostalih naselja još više ističu pokazatelji o prve tri najzastupljenije djelatnosti u socijalno-ekonomskoj strukturi naselja Krivoputske mikroregije 2001. godine (Tab. 12).

narstvo i proizvodno zanatstvo). Tercijarni sektor obuhvaća stanovništvo zaposleno u neproizvodnim gospodarskim granama (uslužno zanatstvo, trgovina, promet, ugostiteljstvo, bankarstvo i slično). Kvartarni sektor obuhvaća stanovništvo zaposleno u negospodarskim (društvenim i državnim) djelatnostima koje se financiraju iz proračuna (uprava, obrana, prosvjeta, zdravstvo, znanost, kultura i slično). 
Tablica 12: Gospodarska usmjerenost (tri vodeće djelatnosti) po naseljima Krivoputske mikroregije po naseljima 2001. godine.

\begin{tabular}{|c|r|c|c|c|c|c|c|}
\hline \multirow{2}{*}{ Prostorna cjelina } & \multicolumn{2}{|c|}{$\begin{array}{c}\text { Broj } \\
\text { zaposlenih }\end{array}$} & \multicolumn{1}{|c|}{$\%$} & djelatnost & \multicolumn{2}{c|}{ 2. djelatnost } & \multicolumn{2}{|c|}{ 3. djelatnost } \\
\hline Grad Senj & 2.173 & 12,9 & Prerad. ind. & 12,7 & Hoteli i restor. & 11,6 & Trgovina \\
\hline $\begin{array}{l}\text { Krivoputska } \\
\text { mikroregija }\end{array}$ & 125 & 15,2 & Javna uprava i obr. & 14,4 & Hoteli i restor. & 13,6 & $\begin{array}{c}\text { Poljopr., lov, } \\
\text { šumar. }\end{array}$ \\
\hline - Alan & 4 & 50,0 & Prerađ. ind. & 25,0 & Hoteli / prijevoz & - & - \\
\hline - Krivi Put & 5 & 40,0 & $\begin{array}{c}\text { Poljoprivreda / } \\
\text { prijevoz }\end{array}$ & 20,0 & Trgovina & - & - \\
\hline - Mrzli Dol & 3 & 33,3 & $\begin{array}{c}\text { Poljopr. / trg. / } \\
\text { obraz. }\end{array}$ & - & - & - & - \\
\hline - Podbilo & 11 & 36,4 & Poljopr., lov, šumar. & 18,2 & Hoteli / obrazov. & 9,1 & $\begin{array}{c}\text { Prerad.ind./ trg / } \\
\text { prijevoz }\end{array}$ \\
\hline - Veljun Primorski & 14 & 28,6 & Poljopr., lov, šumar. & 21,4 & Gradevin. / hoteli & 14,3 & Prijevoz i skladišt. \\
\hline - Vrataruša & 88 & 20,5 & Javna uprava i obr. & 13,6 & Hoteli i restor. & 10,2 & Obrazovanje \\
\hline
\end{tabular}

Izvor: 10 .

Dok je najviše stanovnika Vrataruše zaposleno u javnoj upravi i obrani, u četiri od pet gornjačkih naselja najveći broj stanovnika još uvijek egzistenciju ostvaruje od poljoprivrede (u dva slučaja u kombinaciji s lovom i šumarstvom, a u druga dva s trgovinom i obrazovanjem, odnosno prijevozom). To jasno potkrjepljuje postojanje funkcionalne dihotomije u okviru Krivoputske mikroregije, sa sve izrazitijom razvojnom konvergencijom između gornjačkih naselja, naglašenije ovisnih o tradiconalnim gospodarskim djelatnostima, i Nove Vrataruše (priobalnog dijela istoimenog statističkog naselja), usmjerene na djelatnosti kvartarnog i tercijarnog sektora. Dinamična socijalno-ekonomska transformacija Vrataruše odrazila se i u odgovarajućem procesu urbanizacije, tako da je već 1991. godine zadovoljavala kriterij za «jače urbanizirano naselje». Taj je proces dodatno ubrzan od sredine 1990-ih godina, s akceleracijom u posljednjem desetljeću.

\section{ZAKLJUČNE POSTAVKE}

Zloženi pregled demografskog razvoja Krivoputske mikroregije omogućuje izdvajanje nekoliko zaključnih postavki.

Primorska padina Velike Kapele na području Grada Senja ima jasno izražene karakteristike tradicionalne prostorne cjeline, a u manjoj mjeri i nodalno-funkcionalne regije (jer u uvjetima depopulacije i jačanja povezanog života slabi funkcionalno-gravitacijski utjecaj Krivoga Puta kao središnjeg naselja).

Današnja struktura naseljenosti u Krivoputskoj mikroregiji utemeljena je u prvim desetljećima 17. stoljeća. Od naseljavanja društveno-gospodarski razvoj bunjevačkih doseljenika odvijao se u okviru porodičnih zadruga, a od sredine 18. stoljeća do 1870-ih godina i političko-pravnog sustava Vojne krajine. Nakon razvojačenja Krajine demografski razvoj mreže naselja temeljno je determiniran iseljavanjem prekobrojnog stanovništva iz tog gorsko-krškog prostora, niske prirodne i gospodarske nosivosti. Tadašnji egzodus u uvjetima agrarne prenaseljenosti odrazio se u depopulaciji tijekom osamdesetih i devedesetih godina 19. stoljeća. No, od početka 20. stoljeća priraštaj je ponovo nadmašio intenzitet iseljavanja, tako da je uoči Prvoga svjetskog rata (1910. godine) dosegnuta najviša razina naseljenosti (3.169 stanovnika, odnosno $35 \mathrm{st} . / \mathrm{km}^{2}$ ). Nakon toga, počinje kontinuirana depopulacija, posebno intenzivna od početka 1960-ih godina pod utjecajem polariziranog razvoja (urbanizacije) Hrvatske i zapošljavanja u inozemstvu. Zahvaljujući pojačanom doseljavanju u priobalni dio naselja Vrataruša od početka 1980-ih godina, u posljednjem međupopisnom razdoblju, 1991.-2001. ponovo je zabilježen manji porast broja stanovnika mikroregije. 
Složeniji društveno-gospodarski razvoj šireg područja Krivoputske regije, prije svega gradskih naselja - Senja, Rijeke i Zagreba, od početka 1960-ih godina potaknuo je postupno sve jače socijalno prestrukturiranje (deagrarizaciju), a od 1980-ih godina i polarizaciju unutar mreže njenih naselja. S jedne strane izdvojio se priobalni dio Vrataruše (uvjetno Nova Vrataruša), koja se posljednjih desetljeća razvija kao prigradsko naselje grada Senja, a s druge - sva ostala, tzv. gornjačka (na visoravni kapelske padine) naselja (Alan, Krivi Put, Mrzli Dol, Podbilo, Veljun Primorski i stari dio Vrataruše) koja su zadržala izrazita obilježja ruralne periferije. Ta dva prostorna pola karakteriziraju divergentne razvojne tendencije, što se neposredno odražava u dinamičkim i strukturnim promjenama njihova stanovništva u recentnom razdoblju. Među gornjačkim naseljima nešto manje negativnim obilježjima analiziranih indikatora izdvaja se Alan, što je moguće objasniti naglašenijom gravitacijom njegova malobrojnog stanovništva (11 stanovnika 2001.) prema Novom Vinodolskom, odnosno Crikveničkom primorju.

Zbog pozitivnog selidbenog salda Vrataruše 1991. - 2001. (82 stanovnika ili 45,6\% u odnosu na 1991.), opće kretanje stanovništva Krivoputske mikroregije u posljednjem međupopisnom razdoblju ima obilježja tipa $\mathrm{I}^{3} \mathrm{~s}$ trendom slabe regeneracije imigracijom. Pritom, međutim, treba naglasiti da kretanje u većini gornjačkih naselja pripada tipu $\mathrm{E}^{4} s$ trendom - demografsko izumiranje.

Zbog dugotrajnog iseljavanja pretežno mlađih dobnih skupina stanovništva, promatrani prostor karakterizira ubrzani proces starenja (dobni sastav pripada tipu 6 s obilježjem «izrazito duboke starosti»), pri čemu se nešto manje nepovoljnim obilježjima izdvajaju Alan i Vrataruša.

Po obrazovnoj strukturi Krivoputska mikroregija zaostaje za prosjekom Grada Senja, što posebno dolazi do izražaja u gotovo dvostruko većem udjelu stanovnika bez škole is nezavršenom osnovnom školom. I tu se nešto povoljnijim obilježjima izdvajaju Alan i Vrataruša, dok ostala četiri naselja u prosjeku imaju natpolovičan udio takvih stanovnika.

Krivoputska mikroregija ima mali broj poljoprivrednika (svega 12, od čega 10 aktivnih). U socijalnoekonomskoj strukturi relativno istaknuto značenje ima primarni sektor djelatnosti, pri čemu Vrataruša ima manji, a gornjačka naselja gotovo trostruko veći udio zaposlenih u njegovim djelatnostima prema prosjeku Grada Senja. Razlike u razvijenosti i stupnju preobrazbe upotpunjuju i podaci da u socijalnoekonomskoj strukturi Vrataruše prevladavaju djelatnosti kvartarnog (javna uprava i obrana, obrazovanje) i tercijarnog sektora (hoteli i restorani), a kod gornjačkih naselja poljoprivreda, lov i šumarstvo. Pritom je ponovo izuzetak Alan u kojem prevladava orijentacija na prerađivačku industriju.

Navedene razlike u razvojnim tenedencijama, prije svega funkcionalnoj usmjerenosti, neposredno se odražavaju i u fizionomskim obilježjima naselja promatranog prostora. Tako Vrataruša (priobalni dio naselja) ima obilježja jače urbaniziranog naselja, dok ostala, gornjačka, naselja karakterizira tzv. depopulacijski krajolik.

Na temelju izloženih obilježja demografskog razvoja Krivoputske mikroregije moguće je zaključiti da će se postojeće razvojne tendencije nastaviti i u doglednoj budućnosti. Paralelno s njima odvijat će se i naznačeni procesi prostorne diferencijacije i lokalne polarizacije. Zbog malog broja stanovnika, uznapredovalog procesa starenja i registriranog trenda demografskog izumiranja, u gornjačkim naseljima nastavit će se destabilizacija postojeće naseljenosti s perspektivom da neka među njima ostanu bez stalnih stanovnika. S druge pak strane, priobalni dio naselja Vrataruša (Nova Vrataruša), čiji je pozitivan demografski razvoj posljedica prostornog preslojavanja stanovništva gornjačkih naselja, sve više će se razvijati kao sastavni dio grada Senja.

Unatoč negativnim demografskim procesima u gornjačkim naseljima Krivoputske mikroregije, veličina prostora i vrijedna resursna osnova, uključujući prirodno i kulturno-tradicijsko naslijeđe, nalažu potrebu sveobuhvatnog promišljanja stabilizacije naseljenosti u tom dijelu ruralne periferije Grada Senja. To više, što je kroz to područje trasiran budući infrastrukturni koridor nacionalnog značenja (dionica autoceste Rijeka-Žuta Lokva), a krajem 2008. godine u neposrednoj blizini izgrađene i prve vjetroelektrane u sklopu «vjetroenergetskog polja» Vrataruše. Pritom je otežavajuća okolnost što jednako nepovoljni demo- 
grafski procesi - trend demografskog izumiranja - karakteriziraju i šire područje, gradove Senj i Otočac, odnosno Ličko-senjsku županiju (Pejnović 2004:23-46). Unatoč postojećim problemima, u novije vrijeme stekle su se povoljne okolnosti koje otvaraju i drugačije razvojne perspektive tim i sličnim ruralnim područjima. To se odnosi na sljedeće: prvo, promjenu vrijednosne paradigme u postindustrijskom razdoblju čiji je sastavni dio drugačiji, proaktivan, pristup ruralnim područjima; drugo, aktualnu (globalnu i nacionalnu) gospodarsku krizu koja prije svega i najviše pogađa gradove (gradsko stanovništvo), što ističe potrebu revalorizacije resursne osnove šireg prostora; treće, postojanje razrađenog instrumentarija ruralnog razvoja sadržanog u strategiji ruralnog razvoja - ECOVAST-a i LEADER-ovu pristupu razvoju ruralnih područja, odnosno strategiji ruralnog razvoja Hrvatske; i četvrto, poticajne mjere iz predpristupnih fondova, a perspektivno i strukturnih fondova EU za usklađeniji prostorni (regionalni i lokalni) razvoj.

$\mathrm{Na}$ taj način, promišljenim izborom razvojnih projekata, temeljenih na poredbenim prednostima Krivoputske regije (prostrano zaleđe iznad uskog pojasa podvelebitskog priobalja, s funkcijom "prirodne terase» i tranzitnim položajem, uz trasu buduće auto-ceste), trebalo bi potaknuti nove razvojne inicijative s ciljem zaustavljanja negativnih procesa u tom dijelu ruralne periferije Grada Senja.

\section{IZVORI:}

1. Kesić, B., Luković, G., Stipetić, V. (1973): Kretanje stanovništva i životnih događaja u Lici od 1857. - 1971 godine. U: Lika u prošlosti i sadašnjosti, zbornik 5, Historijski arhiv u Karlovcu, Karlovac, 493-504.

2. Korenčić, Mirko (1979): Naselja i stanovništvo SR Hrvatske 1857.-1971., Djela JAZU, knj. 54, Zagreb.

3. Narodnosni i vjerski sastav stanovništva Hrvatske 1880. - 1991. po naseljima, knj. 4, Državni zavod za statistiku, Zagreb, 1998.

4. www.dzs.hr (Popis stanovništva 2001. godine).

5. Prirodno kretanje stanovništva 1963.-2007., Interna baza podataka DZS, Zagreb.

6. www.dzs.hr (Popis stanovništva 2001. godine, Stanovništvo prema spolu i starosti, po naseljima).

7. Popis stanovništva, kućanstava i stanova 2001. godine, Stanovništvo staro 15 i više godina prema spolu i završenoj školi, po naseljima, DZS, Zagreb.

8. Popis stanovništva, kućanstava i stanova 2001. godine. Stanovništvo prema aktivnosti i spolu, po naseljima, DZS, Zagreb.

9. Popis stanovništva 2001. godine. Poljoprivredno stanovništvo prema aktivnosti i spolu, po naseljima, DZS, Zagreb.

10. Popis stanovništva 2001. godine. Stanovništvo prema djelatnostima, po naseljima, DZS, Zagreb.

\section{LITERATURA:}

BOGOVIĆ, Mile (2008): Župa Krivi Put, u: Živjeti na Krivom Putu, sv. I (ur. Milana Černelić, Marijeta Rajković, Tihana Rubić), Sveučilište u Zagrebu, Filozofski fakultet, Odsjek za etnologiju i kulturnu antropologiju, FF-Press i Gradski muzej Senj: Zagreb, 69-75.

ČILAŠ ŠIMPRAGA, Ankica (2008): O krivoputskome govoru, u: Živjeti na Krivom Putu, sv. I (ur. Milana Černelić, Marijeta Rajković, Tihana Rubić), Sveučilište u Zagrebu, Filozofski fakultet, Odsjek za etnologiju i kulturnu antropologiju, FF-Press i Gradski muzej Senj: Zagreb, 69-75.

FRAS, Franjo Julije (1988): Topografija Karlovačke vojne krajine: Mjestopis iz godine 1835., Ličke župe, Gospić.

FRIGANOVIĆ, Mladen (1990): Demogeografija: stanovništvo svijeta, Školska knjiga, Zagreb.

FÜRST-BJELIŠ, Borna (1996): Pristup definiciji prostornog pojma tradicionalne regije, u: Zbornik radova I. hrvatskoga geografskog kongresa (Geografija u funkciji razvoja Hrvatske), Zagreb, 12. i 13. listopada 1995., Zagreb, 326-330. 
LAGINJA, Ivana (ur.) (2004): LEADER, od inicijative do metode: Vodič za poduku o LEADER-ovu pristupu, ZOE - Centar za održivi razvoj ruralnih krajeva, Zagreb (www.zoe-centar.hr).

LJUBOVIĆ, Blaženka (2008): Zemljopisni položaj i pregled novije povijesti Krivog Puta, u: Živjeti na Krivom Putu, sv. I (ur. Milana Černelić, Marijeta Rajković, Tihana Rubić), Sveučilište u Zagrebu, Filozofski fakultet, Odsjek za etnologiju i kulturnu antropologiju, FF-Press i Gradski muzej Senj: Zagreb, 49-67.

NEJAŠMIĆ, I. (2005): Demogeografija: stanovništvo u prostornim odnosima i procesima, Školska knjiga, Zagreb.

PAVIČIĆ, Stjepan (1990): Seobe i naselja u Lici, Posebna izdanja Muzeja Like, knj. 1, Gospić.

PEJNOVIĆ, Dane (2004): Lika: Demographic Development under Peripheral Conditions, Hrvatski geografski glasnik, 66/2, Zagreb, 23-46.

PEJNOVIĆ, Dane (2007): Demografski razvoj i perspektiva naselja Krasno, u: Krasno: monografija u povodu 200. obljetnice Župe sv. Antuna Padovanskoga i 170 godina školstva u Krasnu (ur. Joso Vukelić), Krasno - Rijeka, 37-61.

PEPEONIK, Valerija (ur.) (1984): Strategija za ruralnu Europu, ECOVAST - Europsko vijeće za sela i male gradove, Hrvatska sekcija, Zagreb.

RAJKOVIĆ, Marijeta (2008): Pregled suvremenih migracija Krivopućana, u: Živjeti na Krivom Putu, sv. I (ur. Milana Černelić, Marijeta Rajković, Tihana Rubić), Sveučilište u Zagrebu, Filozofski fakultet, Odsjek za etnologiju i kulturnu antropologiju, FF-Press i Gradski muzej Senj: Zagreb, 79-94.

RAJKOVIĆ, Marijeta, JURKOVIĆ, Jasmina (2008): Primorski Bunjevci Krivopućani na području Virovitice, u: Živjeti na Krivom Putu, sv. I (ur. Milana Černelić, Marijeta Rajković, Tihana Rubić), Sveučilište u Zagrebu, Filozofski fakultet, Odsjek za etnologiju i kulturnu antropologiju, FF-Press i Gradski muzej Senj: Zagreb, 95-119.

ŠARIĆ, Marko (2008): Bunjevci u ranom novom vijeku: Postanak i razvoj jedne predmoderne etnije, u: Živjeti na Krivom Putu, sv. I (ur. Milana Černelić, Marijeta Rajković, Tihana Rubić), Sveučilište u Zagrebu, Filozofski fakultet, Odsjek za etnologiju i kulturnu antropologiju, FF-Press i Gradski muzej Senj, Zagreb, 15-43.

WERTHEIMER-BALETIĆ, Alica (1999): Stanovništvo i razvoj, Mate, Zagreb. 